\title{
Enhancing Food and Livelihood Security of Highland Temperate Rainfed Ecologies Using Improved Maize Cultivars
}

\author{
M. Ashraf Ahangar ${ }^{* 1}$, S. Najeeb ${ }^{2}$, F. A. Sheikh ${ }^{1}$, A. G. Rather ${ }^{1}$ and N. A. Teeli ${ }^{1}$ \\ ${ }^{1}$ Mountain Crop Research Station Sagam Anantnag, Kashmir (192 102), India \\ ${ }^{2}$ Mountain Research Centre for Field Crops Khudwani, Sher-e- Kashmir University of Agricultural Sciences and \\ Technology, Kashmir (192 102), India
}

\section{Article History}

Manuscript No. AR1349

Received in $24^{\text {th }}$ March, 2015

Received in revised form $30^{\text {th }}$ September, 2015

Accepted in final form $4^{\text {th }}$ October, 2015

\section{Correspondence to}

*E-mail: mashrafjs@gmail.com

\section{Keywords}

High yielding, pest resistant, maize

composites, temperate ecologies

\begin{abstract}
In temperate mountain agro-ecologies of India, cultivation of landraces and farmer's varieties using traditional methods is the main reason for low productivity of maize in potential niches. Painstaking efforts made at Mountain Crop Research Station, Sagam during kharif 2008 and 2009 resulted in two modern, high yielding maize composites viz., Shalimar Maize Composite 3 (SMC-3) and Shalimar Maize Composite 5 (SMC-5) with all the traits liked by the resource poor and marginal farmers. SMC-3 and SMC5 showed grain yield superiority of 10.5 and $14.8 \%$ over the best commercial check (C15) and 42.9 and $48.7 \%$ superiority over local check, respectively. SMC-3 variety also resulted in $6.6 \%$ and $49.65 \%$ increase in stover yield over commercial check (C15) and local check, respectively. On the otherhand, SMC-5 showed 12.3 and 58.31\% superiority in stover yield over commercial check and local check, respectively. Thus, both these varieties gave higher net returns and B:C ratio vis-a-vis check. Further, they showed moderate resistance against Turcicum leaf blight and common rust and resistance to stem borer, blue beetle and aphids. Application of $100 \%$ recommended dose of fertilizers long spacing of $60 \times 20 \mathrm{~cm}^{2}$ can be recommended as it resulted in significantly higher grain yield. SMC-5 contained elevated levels of tryptophan (20\%), lysine $(46 \%)$ and sugar contents $(16 \%)$ over commercial check. The mass adoption of farmer preferred and reasonably priced, high yielding composite varieties can give a boost to maize productivity and profitability.
\end{abstract}

\section{Introduction}

Maize ranks third in volume among the cereals grown in India. Its contribution to the country's total production of food grain is $8.65 \%$ in 2012-13 (Ministry of Agriculture, 2013). Maize has traditionally been grown as a staple food for household consumption. However, the increasing commercial orientation of India's agricultural economy has resulted in a rising demand for maize, especially for feed and industrial use. Private maize seed companies have been established in many important maize-producing states, offering farmers a wide range of improved open-pollinated varieties (OPVs) and hybrids but most of them are suitable for favourable production conditions and cannot perform well in marginal production environments with highly unfavourable agro-climatic conditions. Maize is the second most important crop after rice in the state of Jammu and Kashmir (India), cultivated on an area of 302 thousand hectares with annual production of 527 thousand tons and average productivity of $15.7 \mathrm{q} \mathrm{ha}^{-1}$ (Najeeb and Shafiq, 2012).
The Kashmir valley (longitude 73.0-74.2 ${ }^{\circ} \mathrm{E}$ and latitude $33-$ $34^{\circ} \mathrm{N}$ ) is agroclimatically a typical temperate region, wherein maize is being cultivated at an altitude range of 1850-2500 $\mathrm{m}$ above mean sea level as sole crop or intercropped with Rajmash (pooled type pulse beans). Maize is kharif season crop and about $85 \%$ of the cropped area is rainfed, generally grown on marginal lands of hilly terrains of the state. The major constraints to increase maize production primarily involves predominance of cultivated landraces having low yield potential and susceptibility to various biotic and abiotic stresses, non-availability of vital inputs, inaccessibility, scattered and small land holding together with cultivation on rainfed and marginal conditions. In addition to reduction in grain yield, diseases and other stresses cause immense damage to crop straw the only source of fodder in Kashmir valley which often remains cut off from outside world for months together during winter (Asif and Gul Zafar, 2009). The average productivity of maize under such ecologies is quite deplorable 
$\left(1.5 \mathrm{t} \mathrm{ha}^{-1}\right)$ when compared to national productivity of 2.5 tons ha $^{-1}$ (Najeeb et al., 2012). This gap in productivity can also be attributed to lack of adoption of integrated maize management technologies by farmers on large scale.

In fact diversification in food habits and the change in consumer preference, besides the revolutionary change in standards of living of the people, the maize is gaining large demand. Other sectors directly interrelated with increased demand for maize are, cattle population, mushrooming poultry sector and very good liking for roasted cobs as ready source of food. Fine grain flour (Makkai atta) obtained after grinding sun dried cobs is used for making bread and is very much preferred even in urban areas and rough grain flour (Makaisatoo) prepared after sun drying followed by roasting and grinding is the main breakfast food in the rural Kashmir. In order to meet out the demand as incited by the above said-factors under the conditions of land resources being getting exhausted, competition with other remunerative crops like apple and steady population growth $\left(2 \%\right.$ year $\left.^{-1}\right)$, as a result gains in yield quantum rather than adding to planted area must be the major source of increased maize production. In order to enhance productivity there is immediate need to breed and deploy high yielding and disease resistant maize varieties by replacing the low yielding farmer's varieties and obsolete landraces. In the backdrop of these facts the much improved maize composite varieties, namely Shalimar Maize Composite 3 and Shalimar Maize Composite 5 were developed to replace low yielding farmers varieties and to achieve food, profitability and livelihood security.

\section{Materials and Methods}

To evolve high yielding, early maturing and disease resistant maize composites having in-built tolerance to cold, Shalimar Maize Composite-3 has been synthesized during kharif 2005 by bulking together equal number of $F_{2}$ seeds of all possible cross combinations of four parents viz., Pahalgam Yellow, Local Lidroo, C 15 and Pop. 85C4 followed by three cycles of recombination and selection (Half-sib) for yield, disease and cold tolerance in the target environment $(>1800 \mathrm{~m}$ above mean sea level) as proposed by Lamkey and Kendall (1992). Pop. 85C4 (EC439397) received from CIMMYT and C 15 (released and popular composite under higher altitudes) have good yield potential, whereas Pahalgam Yellow and Local Lidroo, the indigenous landraces of Pahalgam area of district Anantnag (Jammu and Kashmir, India) are short duration well adapted high altitude varieties with in-built tolerance to cold but are low yielders and susceptible to foliar diseases particularly to Turcicum leaf blight and common rust.

Similarly a high yielding and quality protein maize variety, Shalimar Maize Composite ${ }^{-5}$ with early maturity, disease resistance and tolerance to cold, has been synthesized by mass selection of early genotypes from the population of SO3HI HQ in the target environment during kharif 2005. SO3HI HQ, a QPM maize population was received from CIMMYT and after evaluation was found to have lacked adaptation to high altitude conditions of Kashmir due to late maturity. Initially 30 early plants were selected and equal quantity of seed of these plants was composited and allowed to random mate in isolation followed by three cycles of recombination and selection (Halfsib) for high yield, early maturity, quality protein, and disease and cold tolerance in the target environment.

The varieties SMC-3 and SMC-5 were evaluated during kharif 2008 and 2009 under research station trials for yield and morpho-agronomic attributes at Mountain Crop Research Station (MCRS) Sagam (SKUAST-K) situated at an altitude of $2290 \mathrm{~m}$ above mean sea level. The experiments were laid in a completely randomized block design with tree replication per treatment. To judge the performance of the varieties in the farmers fields the varieties were tested under ninikit trials during kharif 2008 and 2009. The minikit testing in the farmer's fields was carried out at different locations covered all the districts of Kashmir valley in collaboration with District Agricultural Officers of the State Department of Agriculture. The improved composites were evaluated at MCRS, Sagam under various agronomic management practices viz., different fertilizer and spacing levels to devise the most effective combination for optimum yield returns. Fertility levels were $100 \%$ recommended fertilizer dose RDF $\left(60,40\right.$ and $20 \mathrm{k} \mathrm{ha}^{-1}$ of $\mathrm{N}, \mathrm{P}_{2} \mathrm{O}_{5}$ and $\mathrm{K}_{2} \mathrm{O}$ respectively and 15 tons of FYM ha- ${ }^{-1}$ ), $75 \% \mathrm{RDF}, 125 \% \mathrm{RDF}$ and $150 \% \mathrm{RDF}$ along with three spacing levels of $45 \times 20 \mathrm{~cm}^{2}, 60 \times 20 \mathrm{~cm}^{2}$ and $75 \times 20 \mathrm{~cm}^{2}$. The treatments were arranged in a completely randomized block design with three replications per treatment.

The varieties were screened against Turcicum leaf blight, and common rust and various insect pests viz., stem borer, blue beetle, cutworm and aphid during kharif 2008 and 2009 by following CIMMYT Standard Evaluation System (Mugo et al., 2001). 1-5 scale (Payak and Sharma, 1982) was used for scoring the disease reaction. $1=$ Resistant (up to $6 \%$ disease intensity), $2=$ Moderately resistant (7-25\%), 3=Moderately susceptible (26-50\%), 4=Susceptible (51-75\%), 5=Highly susceptible (>76\%). SMC-3 and SMC-5 were tested under all India Coordinated Maize improvement programme in the North Hill Zone of India during 2008 and 2009 to assess the performance of the varieties across different hill zones.

The quality analysis for amino acid profiling and estimation of sugar content was done in Biochemistry laboratory of DMR New Delhi.

\section{Results and Discussion}

The mean performance (over locations and years) of SMC-3 
and SMC-5 with respect to grain yield was 55.1 and $57.2 \mathrm{q} \mathrm{ha}^{-1}$, respectively, with a superiority of 10.5 and $14.8 \%$ over the best commercial check (C15) and 42.9 and $48.7 \%$ superiority over local check. SMC-3 showed the stover yield superiority of 6.6 and $49.65 \%$ over commercial check (C15) and local check, respectively, while SMC-5 showed the stover yield superiority of 12.3 and $58.31 \%$ over $\mathrm{C} 15$ and local check respectively (Figure 1). The results of minikit tests revealed that average production of SMC-3 over locations and years was $36.5 \mathrm{q} \mathrm{ha}^{-1}$ with a superiority of $18.5 \%$ against best check C-15. Similarly SMC-5 showed yield improvement of $23.9 \%$ over $\mathrm{C} 15$ in the minikit with the mean productivity of $48.3 \mathrm{q} \mathrm{ha}^{-1}$ (Table 1).

Table 1: Average yield performance of varieties over years and locations in the Minikit trials conducted across Kashmir valley

\begin{tabular}{llcccc}
\hline \multirow{2}{*}{$\begin{array}{l}\text { Sl. } \\
\text { no. }\end{array}$} & District & $\begin{array}{c}\text { No. of } \\
\text { locations }\end{array}$ & \multicolumn{2}{c}{$\begin{array}{c}\text { Mean yield } \\
\left.(\mathrm{q} \mathrm{ha})^{-1}\right)\end{array}$} & $\begin{array}{c}\text { \% Increase } \\
\text { over check }\end{array}$ \\
\cline { 3 - 5 } & & & SMC-3 & C15(check) & \\
\hline 1. & Budgam & 2 & 30.30 & 26.00 & 16.50 \\
2. & Baramulla & 2 & 28.67 & 24.17 & 18.61 \\
3. & Kulgam & 2 & 48.53 & 42.43 & 14.37 \\
4. & Ganderbal & 2 & 32.32 & 25.00 & 29.28 \\
5. & Bandipora & 2 & 28.43 & 27.70 & 2.63 \\
6. & Anantnag & 2 & 51.00 & 45.63 & 11.76 \\
7. & Kupwara & 2 & 36.06 & 24.56 & 46.82 \\
& Average & & 36.47 & 30.78 & 19.99 \\
District & & SMC-5 & C15(check) & \\
1. & Budgam & 2 & 45.32 & 40.20 & 12.73 \\
2. & Baramulla & 2 & 56.45 & 42.00 & 34.40 \\
3. & Kulgam & 2 & 53.00 & 44.58 & 18.88 \\
4. & Ganderbal & 2 & 42.38 & 36.03 & 17.62 \\
5. & Bandipora & 2 & 47.40 & 37.42 & 26.67 \\
6. & Anantnag & 2 & 53.09 & 42.54 & 24.80 \\
7. & Kupwara & 2 & 40.42 & 30.00 & 34.73 \\
& Average & & 48.29 & 38.96 & 24.26 \\
\hline
\end{tabular}

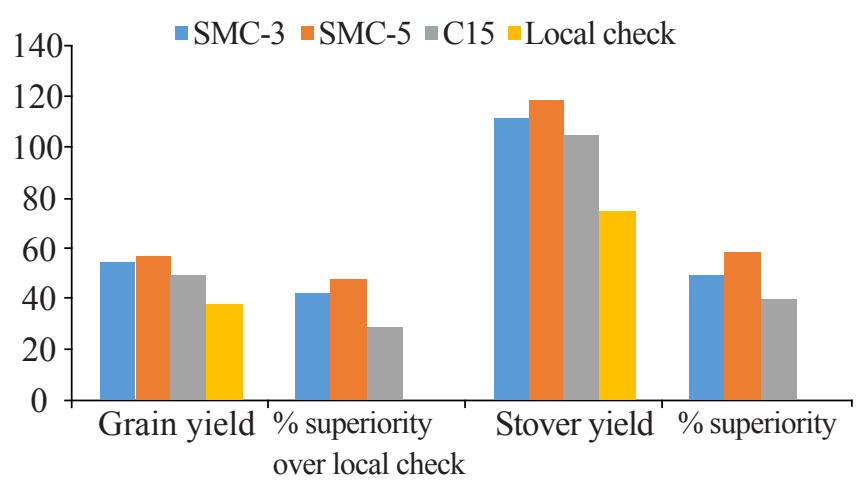

Figure 1: Average yield performance of varieties over years and locations in research station trials
The results of multi-location trials for SMC-3 and SMC-5 conducted in collaboration with All India Coordinated Maize Improvement Project for North Hill Zone India revealed that the variety SMC-3 produced average yield of $46 \mathrm{q} \mathrm{ha}^{-1}$ with highest yield of $52.85 \mathrm{q} \mathrm{ha}^{-1}$ at Almora Utrakhand while as, SMC-5 showed average productivity of $55.10 \mathrm{q} \mathrm{ha}^{-1}$ and stood at rank $2^{\text {nd }}$ and recorded the maximum yield of $71.5 \mathrm{q} \mathrm{ha}^{-1}$ at Almora followed by $66.9 \mathrm{q} \mathrm{ha}^{-1}$ at Bajaura.

Most of the improved OPVs and hybrids developed in India are suitable for favourable production conditions. Although public sector breeding programs have produced a somewhat broader range of materials than private companies but neither sector has placed any emphasis on developing materials for marginal production environments with highly unfavourable agroclimatic conditions (e.g., drought or water logging, extreme heat or cold, severely nutrient-deficient or imbalanced soils) (Pal et al., 1998). Entire maize grown ecology of Kashmir is by nature typically marginal, were farmers are poor who hardly afford the high cost seeds developed by the private sector and is not feasible at all for such kinds of agro ecosystems. The major challenge to maize crop in temperate mountain agro ecologies particularly of Kashmir valley is the prevailing short favourable growing season (125-130 days) and therefore demands early maturing varieties. In fact the early maturing varieties of 90-100 days duration bred in other part of India and the improved material frequently being received from CIMMYT of similar duration do not mature even in 140 days under such conditions. The crop is sown from $2^{\text {nd }}$ to $4^{\text {th }}$ week of April and seed remains un-germinated for weeks together due to unexpected fall in temperature because of low to medium snowfall on the adjoining mountains and these cold spells may occur at different crop growth stages. As a result SMC-3 and SMC-5 with cold tolerance and early maturity have a very good role to play in the economy of maize growers under such agro ecosystems.

The strategies of deploying the newly developed improved composites will help in significant increase in maize productivity unit area ${ }^{-1}$ presently in quite dismal status. The released composites (SMC-3 and SMC-5) have very high yield potential of 5.5-6.0 $\mathrm{t} \mathrm{ha}^{-1}$ as compared to predominant landraces of 1.5-2.0 q ha-1. In marginal areas, where yield levels are low, price of hybrid seed is high and fertilizer application is constrained, it is more profitable for resource-poor farmers to use OPVs or recycled OPVs than to purchase new hybrid seeds annually (Pixley and Banzinger, 2001).

The results of agronomic manipulations for SMC-3 and SMC5 revealed that maximum yield potential was observed by following the spacing of $60 \times 20 \mathrm{~cm}^{2}$ and $100 \%$ recommended fertility dose (60, 40 and $20 \mathrm{k} \mathrm{ha}^{-1}$ of $\mathrm{N}_{2} \mathrm{P}_{2} \mathrm{O}_{5}$ and $\left.\mathrm{K}_{2} \mathrm{O}\right)$ and $15 \mathrm{t}$ of FYM ha- ${ }^{-1}$ (Table 2). Results of an experiment conducted 
Table 2: Average mean performance of the varieties over years (2008 and 2009) with regard to different fertilizer doses and spacing

\begin{tabular}{|c|c|c|c|}
\hline \multirow[t]{2}{*}{ Fertility levels } & \multicolumn{3}{|c|}{ Grain yield $\left(\mathrm{q} \mathrm{ha}^{-1}\right)$} \\
\hline & $\begin{array}{c}\text { Shalimar } \\
\text { Maize } \\
\text { Composite-3 }\end{array}$ & $\begin{array}{c}\text { Shalimar } \\
\text { Maize } \\
\text { Composite-5 }\end{array}$ & $\mathrm{C} 15$ \\
\hline $\begin{array}{l}75 \% \text { of recommended } \\
\text { fertilizer dose }\end{array}$ & 48.23 & 53.46 & 46.50 \\
\hline $\begin{array}{l}100 \% \text { of recommended } \\
\text { fertilizer dose }\end{array}$ & 55.28 & 58.23 & 47.80 \\
\hline $\begin{array}{l}125 \% \text { of recommended } \\
\text { fertilizer dose }\end{array}$ & 52.13 & 54.50 & 44.53 \\
\hline $\begin{array}{l}150 \% \text { of recommended } \\
\text { fertilizer dose }\end{array}$ & 51.84 & 51.00 & 42.47 \\
\hline Mean & 51.87 & 54.29 & 45.33 \\
\hline $\mathrm{CD}(p=0.05)$ & & 3.81 & \\
\hline C.V (\%) & & 7.2 & \\
\hline \multicolumn{4}{|l|}{ Spacing } \\
\hline $45 \times 20 \mathrm{~cm}^{2}$ & 51.04 & 54.13 & 49.43 \\
\hline $60 \times 20 \mathrm{~cm}^{2}$ & 53.87 & 57.47 & 54.56 \\
\hline $75 \times 20 \mathrm{~cm}^{2}$ & 47.93 & 53.44 & 47.76 \\
\hline Mean & 50.94 & 55.26 & 50.58 \\
\hline $\mathrm{CD}(p=0.05)$ & & 2.93 & \\
\hline CV (\%) & & 6.64 & \\
\hline
\end{tabular}

$\mathrm{RDF}=60,40$ and $20 \mathrm{k} \mathrm{N}, \mathrm{P}_{2} \mathrm{O}_{5}$ and $\mathrm{K}_{2} \mathrm{O}$ ha ${ }^{-1}$, respectively and 15 tn of FYM ha ${ }^{-1}$

by Raju et al. (1997) during kharif season revealed that the yield attributes, grain and stover yields of maize increased significantly by increase in nitrogen levels from $90 \mathrm{k} \mathrm{N} \mathrm{ha}^{-1}$ to $135 \mathrm{k} \mathrm{N} \mathrm{ha}^{-1}$ under rainfed condition. Yield response of maize varieties was maximum when crop was sown in $2^{\text {nd }}$ week of April with seed rate of $20 \mathrm{k} \mathrm{ha}^{-1}$ for line sowing and $30 \mathrm{k}$ $\mathrm{ha}^{-1}$ for broadcasting. Under high altitude rainfed ecologies farmers generally do not go for line sowing on scattered, undulating and small land holdings. The on-farm studies carried out at Mountain Crop Research Station-Sagam (2290 $\mathrm{m}$ above mean sea level) revealed that, plant population of $83,500 \mathrm{ha}^{-1}$ of SMC-3 and SMC-5 gave the highest grain yield. Farmers in the region are using higher seed rates as compared to recommended seed rate, mainly to reduce a variety of risks and furthermore to get more stover yield which serves as main source of fodder for sustaining plenty of livestock during winter months when the entire valley remains under the snow cover. Other on-farm studies carried out by Paudyal et al. (2001) corroborate these findings, demonstrating a plant population of $66000 \mathrm{ha}^{-1}$ gave the highest grain yield and a field density of at least $53000 \mathrm{ha}^{-1}$ after thinning was recommended while as Prasad and Brook (2005) reported that biomass and grain yield of maize were greatest at $53 \times 103$ plants ha $^{-1}$. To exploit the maximum yield potential of maize varieties, the soil should have optimum fertility level. The major form of soil fertility management practiced by farmers under such agro-ecosystems is by enriching soil through farm yard manure (FYM). Inorganic mineral fertilizers are being used very less by the farmers. Studies have shown that with little or no input of synthetic fertilizers, grain yield of OPV maize cultivars can be comparable or better than that of hybrids (Ojiem et al., 1996; Coulter et al., 2010). While preparing the package of practices of both these varieties, the application of 60,40 and $20 \mathrm{k} \mathrm{ha}^{-1}$ of $\mathrm{N}, \mathrm{P}_{2} \mathrm{O}_{5}$ and $\mathrm{K}_{2} \mathrm{O}$, respectively for rainfed conditions along with $15 \mathrm{t} \mathrm{ha}^{-1}$ of FYM was recommended. The conjunctive use of organic manure and chemical fertilizers can augment the nutrient use efficiency and also enhance the productivity of quality protein maize (Kumar et al., 2005). Negassa et al. (2003) demonstrated that the integrated use of farm yard manure, compost, and bone meal with low dose of NP fertilizers gave comparable maize grain when compared to the yield obtained under the recommended rate of NP fertilizers $\left(110 / 20 \mathrm{k} \mathrm{ha}^{-1}\right)$.

(Figure 2 and 3). demonstrated the moderately resistant

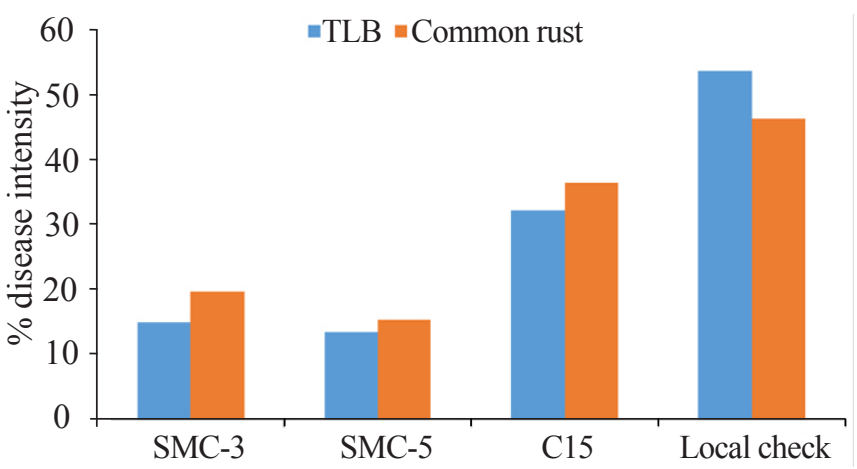

Figure 2: Screening of maize varieties against reaction to major diseases

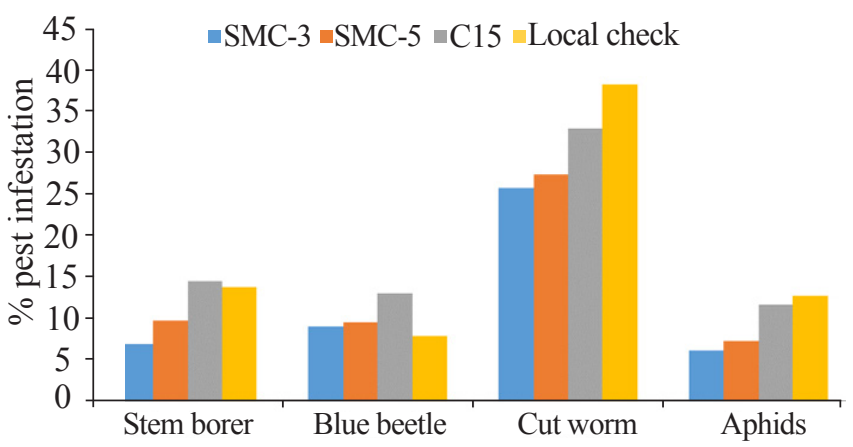

Figure 3: Screening of maize varieties against reaction to major insect pests 
reaction of both the varieties against Turcicum leaf blight, and common rust and resistant to various insect pests viz., stem borer, blue beetle and aphid, however for cutworm the varieties were found moderately susceptible. The cultivated land races of farmers are more susceptible to biotic and abiotic stresses. The diseases particularly turcicum leaf blight and common rust causes enormous damage to crop and the loss in grain yield ranges from 24.5 to $93.4 \%$. The disease epidemics at an early stage cause premature death of blighted leaves which lose their value as fodder also (Harlpur et al., 2009). The mean disease intensity for turcicum leaf blight and common rust categorized both the varieties as moderately resistant with disease score of 2 in $0-5$ evaluation scale. The turcicum leaf blight disease intensity on SMC-3 and SMC-5 was recorded as 14.9 and $13.5 \%$ respectively. The use of resistant cultivars is the most effective, efficient, safe and practical method of obviating loss in crop yield. Inherent resistance or tolerance of crop plants to infection by the pathogen can most likely be a safe alternative and most economical and eco friendly disease management venture (Kumar et al., 2011).

The benefit cost ratio was estimated by calculating total cost of cultivation and the net returns of both the varieties on hectare basis. The values of benefit cost ratio of SMC-3 and SMC-5 were 1.56 and 1.77 , respectively as compared to 1.37 of commercial check C-15 (Table 3). Bangarwa et al. (1989) reported that highest net profit (₹ 4916) was obtained with a plant population of 90000 plants ha $^{-1}$ with application of 180 $\mathrm{k} \mathrm{N} \mathrm{ha}^{-1}$ while as Ameta and Dhakur (2000) reported higher monetary return and $\mathrm{B}: \mathrm{C}$ ratio of maize with narrow row spacing $(60 \mathrm{~cm})$ when compared to wider row spacing $(75$ $\mathrm{cm})$. In one of the estimates if the productivity gets enhanced from present level of $1.5 \mathrm{t} \mathrm{ha}^{-1}$ to just $3.0 \mathrm{tha}^{-1}$, even though the productivity potential in the farmer's fields has been observed as high as $6.6 \mathrm{tha}^{-1}$, additional 150 thousand $\mathrm{t}$ can be produced from high altitude rainfed ecologies that could meet out the demand arising out of different sectors dependent upon maize. Generally the farmers perceive improved maize varieties as higher yielding, profitable and market oriented than the local

\begin{tabular}{lcccc}
\hline Table 3: Benefit/cost ratio analysis $\left(\mathrm{ha}^{-1}\right)$ & of maize varieties \\
\hline Variety & $\begin{array}{c}\text { Cost of } \\
\text { cultivation } \\
(₹)\end{array}$ & $\begin{array}{c}\text { Goss } \\
\text { returns } \\
(₹)\end{array}$ & $\begin{array}{c}\text { Net } \\
\text { returns } \\
(₹)\end{array}$ & $\begin{array}{c}\text { Benefit } \\
\text { cost ratio }\end{array}$ \\
\hline $\begin{array}{l}\text { Shalimar Maize } \\
\text { Composite-3 }\end{array}$ & 35,470 & 91,000 & 55,530 & 1.56 \\
$\begin{array}{l}\text { Shalimar Maize } \\
\text { Composite-5 }\end{array}$ & 35,470 & 98,500 & 63,030 & 1.77 \\
C15 & 35,470 & 84,250 & 48,780 & 1.37 \\
\hline
\end{tabular}

varieties (Cavane, 2011).

Realizing the quality consciousness of the consumers and the trend worldwide, SMC-5 first Quality Protein Maize variety has been developed in this endeavour by SKUAST-Kashmir and recommended for high altitude agro ecology of Kashmir and equivalent ecologies (1800-2250 $\mathrm{m}$ above mean sea level). Quality analysis regarding amino acid profile and sugar content revealed that the variety (SMC-5) contains elevated levels of tryptophan $(20 \%)$, lysine $(46 \%)$ and sugar contents $(16 \%)$ over the best check C15 (Table 4). Quality protein maize has been developed to help reduce human malnutrition in areas where protein deficiency is prevalent and where maize is the major protein source in the diet (Krivanek et al., 2007).

Both the varieties have been characterized for various morphoagronomic traits. SMC-3 is medium in height $(180-200 \mathrm{~cm})$ having semi-erect leaves and mid ear placement at $80-90 \mathrm{~cm}$ with bold kernels. The cob is long conical with dent grains and yellow in colour (Plate 1). The variety has grain yield potential of 5.5-6.0 $\mathrm{t} \mathrm{ha}^{-1}$ at the farmer's field, recommended for high altitude rainfed ecology of Kashmir between 1800-2250 m above mean sea level.

Variety SMC-5 is conical, semi-flint with cap and creamy white in colour with good grain and plant characteristics. The height of the variety ranges from $240-250 \mathrm{~cm}$ with cob placement at $100-120 \mathrm{~cm}$ (Plate 2). The kernels have hard endosperm and protein profile is up to expected level. The grain yield potential in the farmer's field ranges between 5.5-6.0 $\mathrm{t} \mathrm{ha}^{-1}$. The variety matures between 135 to 140 days at an altitude range of 1800-2000 m amsl and 150-155 days at 2000-225 m above mean sea level.

In order to enhance the productivity there is immediate need to

\begin{tabular}{|c|c|c|c|c|c|c|}
\hline \multicolumn{7}{|c|}{ Table 4: Grain quality traits (protein profile) of PS 98 and C15 } \\
\hline Variety & $\begin{array}{c}\text { Protein } \\
(\%)\end{array}$ & $\begin{array}{c}\text { Tryptophan } \\
\text { in protein } \\
(\%)\end{array}$ & $\begin{array}{c}\text { Lysine in } \\
\text { protein } \\
(\%)\end{array}$ & $\begin{array}{l}\text { Sugar } \\
(\%)\end{array}$ & $\begin{array}{c}\text { Starch } \\
(\%)\end{array}$ & $\begin{array}{l}\text { Oil } \\
(\%)\end{array}$ \\
\hline $\begin{array}{l}\text { Shalimar } \\
\text { Maize } \\
\text { Compo } \\
\text { site-5 }\end{array}$ & 8.96 & 0.66 & 2.95 & 4.48 & 64.12 & 4.78 \\
\hline $\begin{array}{l}\mathrm{C} 15 \\
\text { (Comm } \\
\text { ercial } \\
\text { check) }\end{array}$ & 8.47 & 0.55 & 2.02 & 3.85 & 69.72 & 4.70 \\
\hline $\begin{array}{l}\% \\
\text { improve } \\
\text { ment } \\
\text { over C15 }\end{array}$ & - & 20.0 & 46.0 & 16.3 & - & - \\
\hline
\end{tabular}




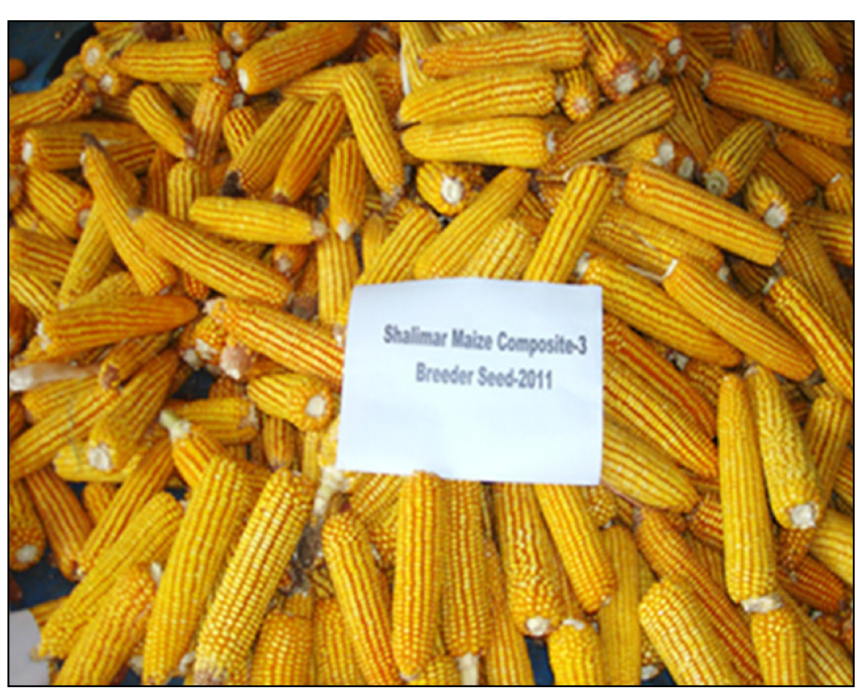

Plate 1: Shalimar Maize Composite-3

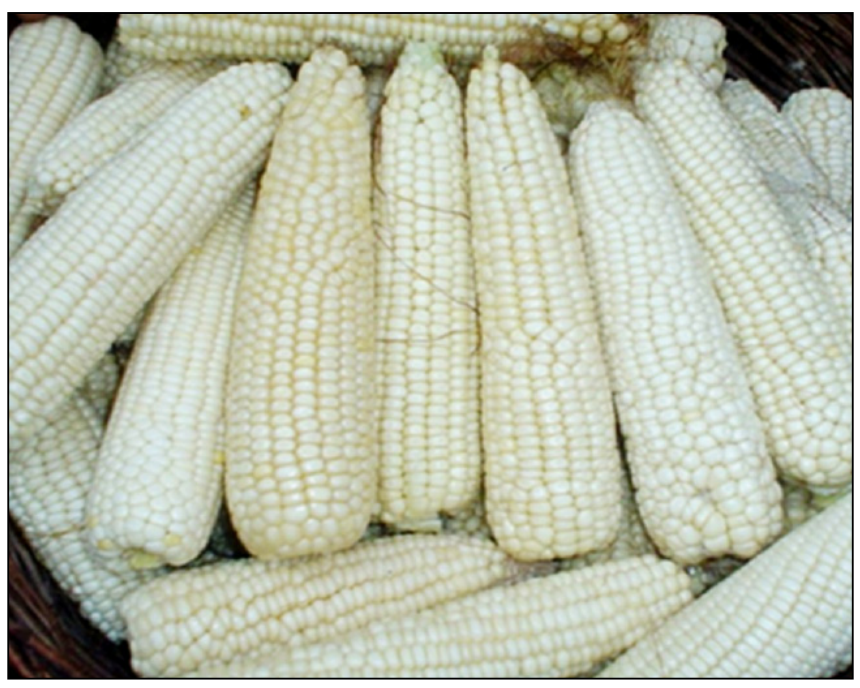

Plate 2: Shalimar Maize Composite-5

popularize these varieties by replacing obsolete varieties and landraces. The strategies will help in increasing production and in bridging the wide gap in productivity at national and state level. This increased productivity at farm level will lead to socio-economic uplift of poor marginal farmers. Recent progress with participatory varietal selection (Joshi and Witcombe, 1996) and breeding (Virk et al., 2003) has led to identification and adoption (Witcombe et al., 1999) of a range of new varieties contributing to higher productivity and agrobiodiversity (Witcombe et al., 2003). Similar progress can be expected with the present results of maize varieties, for onfarm testing, based on sound knowledge of farm conditions and farmers' preferences.

\section{Conclusion}

The development, upscaling and mass adoption of high yielding maize composite varieties possessing farmer preferred traits like early maturity, cold tolerance, moderate resistance to various biotic stresses and above all suitable under rainfed mountain agroecosystems can give a boost to maize industry through increase in production, productivity and farm profitability. Popularization of these varieties in temperate agro-ecologies will increase the production which in turn will lead to socio-economic upliftment of small and marginal farmers.

\section{Acknowledgement}

The authors would like to acknowledge CIMMYT, Mexico for germplasm availability, DMR (New Delhi) for supporting quality analysis.

\section{References}

Ameta, G.S., Dhakar, L.L., 2000. Response of winter maize (Zea mays L.) to nitrogen levels in relation to varying population density and row spacing. International Journal of Tropical Agriculture 18(4), 395-398.

Asif, B.S., Gul, Z., 2009. Evaluation and identification of maize for turcicum leaf blight resistance under cold temperate conditions. Maize Genetics Cooperation Newsletter 83, 31-35.

Bangarwa, A.S., Kairon, M.S., Singh, K.P., 1989. Effect of plant population and nitrogen application on yield and economics of winter maize. Indian Journal of Agronomy 34, 393-395.

Cavane, E., 2011. Farmers' attitude and adoption of improved maize varieties and chemical fertilizers in Mozambique. Indian Research Journal of Extension Education 11, 1-6.

Coulter, J., Sheaffer, C., Moncada, K., Huerd, S., 2010. Corn production. In: Moncada, K.M. Sheaffer C.C. (Eds.), Organic Risk Management. University of Minnesota 9, 1-21.

Haralpur, S.I., Kulkarni, M.S., Kulkarni, S., Patil, B.C., 2009. Assessment of crop loss due to turcicum leaf blight caused by Exsrohilum turcicum (Pass.) Leonard and Suggs in maize. Indian Phytopathology 62(2), 27-31.

Joshi, A., Witcombe, J.R., 1996. Farmer participatory crop improvement 2. Participatory varietal selection, a case study in India. Experimental Agriculture 32, 461-467.

Krivanek, A.F., Groote, H.D., Nilupa, S.G., Alpha, O.D., Dennis, F., 2007. Breeding and disseminating quality protein maize (QPM) for Africa. African Journal of Biotechnology 6, 312-324.

Kumar, A., Gautum, R.C., Singh, R., Rana, K.S., 2005. Growth, yield and economics of maize (Zea mays)-wheat (Triticum aestivum) cropping sequence as influenced 
by integrated nutrient management. Indian Journal of Agricultural Sciences 75, 709-711.

Kumar, S., Gowd, P.K.T., Pant, S.K., Shekhar, M., Kumar, B., Kaur, B., Chchi, H.K., Singh, O.N., Parsanna, B.H., 2011. Sources of resistance to Exserohilum turcicum (Pass.) and Puccinia polysora (Underw.) incitant of Turcicum leaf blight and polysora rust of maize. Arches of Phytopathology and Plant Protection 44, 528-536.

Lamkey, Kendall, R., 1992. Fifty years of recurrent selection in the Lowa stiff stalk synthetic maize population. Maydica 37, 19-28.

Ministry of Agriculture, 2013. 4th Advance Estimates of Food grain Production for 2012-13. Ministry of Agriculture, Government of India 13, 32-33.

Mugo, S., Bergvinson, D.J., Hoisington, D., 2001. Options in Developing Stem borer-Resistant Maize: CIMMYT Approaches and Experiences. Insect Science and its Application 21(4), 409-415.

Najaeeb, S., Zargar, M.A., Ahangar, M.A., Sheikh, F.A., Badri, Z.A., 2012. Maize landraces of Kashmir: present status and future prospects. Maize Genetics Cooperation Newsletter 86, 35-39.

Najeeb, S., Shafiq, A.W., 2012. Improvement of Maize: Emerging Trends in the State of Jammu and Kashmir (India). Maize Genetics Cooperation Newsletter 86, 43-48.

Negassa, W., Negisho, K., Tadesse, T., 2003. Bone meal and rock phosphate as alternative sources of $\mathrm{P}$ fertilizer for maize production. In: Proceedings of the $6^{\text {th }}$ Ethiopian Society of Soil Science Conference, Addis Ababa, Ethiopia, 51-58.

Ojiem, J.O., Ransom, J.K., Wakhonya, H.W., 1996. Performance of hybrid and local maize with and without fertilizer in Western Kenya. In: Proceedings of $5^{\text {th }}$ Eastern and Southern Africa Regional Maize Conference in Arusha, Tanzania, 149-152.
Pal, S., Singh, R.P., Morris, M.L., 1998. Country case studies, India. In: Morris, M.I. (Ed.), Maize Seed Industries in Developing Countries. Lynne Rienner Publishers and CIMMYT, Boulder, Colorado, 401.

Paudyal, K.R., Ransom, J.K., Rajbhadari, N.P., Adhikari, K., Gerpacio, R.V., Pingali, P.L., 2001. Maize in Nepal: Production Systems, Constraints and Priorities for Research, Kathmandu, 48.

Payak, M.M., Sharma, R.C., 1982. Premature drying of maize. In: Techniques for scoring of resistance to important diseases of maize. All India Coordinated Maize Improvement project, IARI. New Dehli, 96-100.

Pixley, K., Banzinger, M., 2001. Open-Pollinated Maize Varieties: A Backward Step or Valuable Option for Farmers. In: Proceedings of the $7^{\text {th }}$ Eastern and Southern Africa Regional Maize Conference. CIMMYT and KARI, 22-28.

Prasad, R.B., Brook, R.M., 2005. Effect of varying maize densities on intercropped maize and soybean in Nepal. Experimental Agriculture 41, 365-382.

Raju, M.S., Srinivas, A., Raja, V., 1997. Performance of promising pre-release maize varieties at different nitrogen levels under rainfed conditions. Annals of Arid Zone 36 (4), 377-379.

Virk, D.S., Singh, D.N., Prasad, S.C., Gangwar, J.S., Witcombe, J.R., 2003. Collaborative and consultative participatory plant breeding of rice for the rainfed uplands of eastern India. Euphytica 132, 95-108.

Witcombe, J.R., Joshi, A., Goyal, S.N., 2003. Participatory plant breeding in maize: A case study from Gujarat, India. Euphytica 130, 413-422.

Witcombe, J.R., Petre, R., Jones, S., Joshi, A., 1999. Farmer participatory crop improvement. IV. The spread and impact of rice varieties identified by participatory variety selection. Experimental Agriculture 35, 471-487. 